\title{
SH23 - Análisis transversal de los estudios de organización y liderazgo de grupos conflictivos
}

\author{
Antonio Minera*,Virginia Jiménez \\ Universidad de San Carlos de Guatemala
}

\section{Resumen}

L os estudios de organización y liderazgo de grupos conflictivos, son mecanismos de análisis de la diversidad de colectivos sociales que ocasionan conflicto contra la naturaleza, la sociedad o el ambiente; según su propia definición. Desarrollados en dos puntos geográficos de importancia histórica y urbanística de la Ciudad de Guatemala que, a través del abandono por parte de las autoridades, permiten las condiciones ideales para la constitución efectiva de este tipo de cúmulos humanos. Constituyendo organizaciones sociales caracterizadas por reproducir la cultura hostil, violenta y delictiva de las zonas urbanas. Por medio de la metodología de observación participante que sustenta su desarrollo, ha sido posible la realización de entrevistas (estructuradas y no estructuradas), con la intención de adentrarse en la realidad que concierne tanto a los miembros activos, como los potenciales reclutas. Dinámica científica que ha permitido conocer especificidades de los diferentes sujetos vinculados con los colectivos en estudio y las relaciones que entre sí mantienen; al igual que el ejercicio de poder que se manifiesta entre ellos y las fuentes de donde el mismo deriva. Repercutiendo en las dinámicas colectivas prevalecientes, susceptibles de diagramar mediante técnicas provenientes de las escuelas estructuralistas. La presencia y dinámicas de cada grupo conflictivo difieren según las áreas urbanas analizadas; sin embargo, los estudios permiten identificar que la transgresión de la norma y el uso de la violencia son característicos en estos colectivos. Aunque sus objetivos y mecanismos de realización sean distintos, aspectos abordados y evidenciados por parte de las teorías sociológicas de la desviación.

Palabras clave: Colectivos humanos, jerarquías de poder, diseño organizacional, dinámica social-urbana, teorías sociológicas de la desviación.

\section{Abstract}

$\mathrm{T}$

he studies of organization and leadership of conflicting groups are mechanisms for analyzing the diversity of social groups that cause conflict against nature, society and the environment; by its definition. Developed in two geographical points of historical and urban significance of Guatemala City, through neglect by the authorities allow the ideal conditions for the effective establishment of this type of human collectives. Constituting social organizations characterized by reproducing the hostile, violent and criminal culture in urban areas. Through the methodology of participant observation that supports its development, it has been possible to conduct interviews (structured and unstructured), with the intention to enter into the reality that concerns to active members and potential recruits. Scientific dynamic that has allowed knowing specificities of the different subjects related to collective study and relationships to each other they maintain; like the exercise of power manifested between them and the sources from which it derives. Impacting in the collective dynamics prevailing, these can be diagrammed through techniques of structuralist school. The presence and dynamics of each group differ according to the urban areas analyzed; however, studies to identify the violation of the rule and the use of violence are characteristic of these groups. Although its objectives and implementation mechanisms are different, addressed aspects and evidenced by the sociological theories of deviance. Although its objectives and implementation mechanisms are different, addressed aspects and evidenced by the sociological theories of deviance.

Keywords: human collectives, hierarchies of power, organization design, social-urban dynamic, sociological theories of deviance. 